\title{
Bir Yönetişim Reformu Olarak Devletin Gülen Yüzü: “Açık Kapı” Uygulaması
}

\author{
As A Governance Reform the Smiling Face of the State: \\ "Açık Kapı" (Open Door) Application
}

\section{Tahsin Güler ${ }^{1}$ - Abdullah Yılmaz ${ }^{2}$}

Başvuru Tarihi: 27.06.2019

Kabul Tarihi: 26.09.2019

Öz

Türkiye'de, 2000'li ylllardan itibaren kamu yönetimi ve kamu hizmetlerinin değişim ve dönüşümünde bilgi iletişim teknolojilerinin önemli payı bulunmaktadır. Kamu yönetimlerinin, piyasa ve birey odaklı bir yapıya evrildiği bu süreçte bir fenomen haline gelmiş olan yönetişim temelli anlayışın altyapısını oluşturdukları için birey ve sivil toplumun güçlendirilmesine öncelik verilmiştir. Bu bağlamda bir yandan kamu hizmetlerinin çeşitliliği, ulaşılabilirliği ve etkinliği artırılırken diğer yandan bireylerin yönetime talep, istek, öneri ve şikayetlerini iletme ihtiyacını karşılayacak iletişim/hak arama mekanizmalarının oluşturulmasına önem verilmiştir. Bu alandaki uygulamalardan en yaygin ve bilinen halkla ilişkiler uygulamaları olarak BİMER ve CIMMER dikkat çekerken, zincirin son halkasını İçişleri Bakanlığı’nın yürütmekte olduğu “Açık Kapı" uygulaması oluşturmuştur.

Valilik ve kaymakamlıklara yapılan başvurulara ilişkin iş ve işlemlerin hızlı ve etkin bir şekilde sonuçlandırılmasını temin ederek sunulan hizmetlerde vatandaş memnuniyetini arttırmak amacını güden "Açık Kapı" uygulaması, teknoloji temelli olmakla birlikte yüz yüze/interaktif görüşme ve danışma imkanı sağlaması bakımından dikkat çekici bir uygulamadır. Çalışmada, yeni bir uygulama olan "Açık Kapı"nın ortaya çıkmasında önemli etkisi bulunan bilgi teknolojileri temelli yönetişim reformlarına değinilerek, "Açık Kapı” uygulamasının işleyişi, BIMER ve CIMMER uygulamalarından farkı, pilot illerden olan Balıkesir ilinde uygulamanin değerlendirmesi ile güçlü ve geliştirilmesi gereken yönleri ortaya konulmaya çalışılmıştır.

Anahtar Kelimeler: Yönetişim, Kamu Yönetimi Reformları, Açık Kapı Uygulaması, Bilgi Teknolojileri

\footnotetext{
${ }^{1}$ Balıkesir Üniversitesi, İIBF, gulert1043@gmail.com, ORCID: 0000-0002-7729-5172

2 Anadolu Üniversitesi, Açı Öğretim Fakültesi, abdullah_y@anadolu.edu.tr, ORCID: 0000-0003-3711-6915
} 


\section{Abstract}

In Turkey, information and communication technologies have had a considerable part in the alteration and transformation of the public administration and public services since the 2000s. As they form the basis for the governance-based cognizance becoming popular in this process during which public administration has evolved into a market and individual-focused structure, the strengthening of the individual and civil society has been attached priority. In this regard, while variety, activity and attainability of social services have been increased on the one hand, on the other hand, importance has been attached to the constitution of communication and rightclaiming mechanisms that will meet the need for individuals conveying demands, wishes, recommendations and complaints to governance. Whereas BIMER and CIMER draw attention as a widely-known and most widespread application of all applications known in this field, The project "Açık Kapı (Open Door)" application, which the ministry of interior is executing, has generated the last link of the chain.

"Açık Kapi"application, in addition to being based on technology, is a remarkable project with respect to the way it provides face to face/interactive consultation and interview possibility, pursuing the goal of increasing the satisfaction of citizens in services offered to them by ensuring the tasks and transactions' regarding the applications made to governorates and district governorates to be concluded rapidly and efficaciously. This article focuses on the functioning of the project "Açık Kapi", its differences from BIMER and CIMER, evaluation of the application in Balikesir, one of the sample provinces, and project's strengths and its parts needing improvements by touching upon information technology-based governance reforms which have great effects on the emergence of the new project "Açık Kapı".

Keywords: Governance, Public Administration Reforms, Open Door (Açık Kapı) Application, Information Technologies

\section{Giriş}

Siyasal, sosyal, kültürel ve ekonomik değişimlerin baş döndürücü bir hızla yaşandığı günümüz dünyasında, kamu yönetimlerinin bu değişimden etkilenmesi kaçınılmazdır. Nitekim kamu yönetimlerinin yükselişine ve kamu hizmetlerinin yayılımına tanık olunan 20. yüzyıl sonlanırken piyasa ekonomisi ve sivil toplumun/bireylerin 21. yüzyıla damgasını vuracak yeni fenomenler olarak sahneye çıtı̆̆g görülmektedir. Bu sahne alışın arkasında gerek dünya gerekse Türkiye özelinde çok çeşitli dinamikler rol oynamaktadır. Bu süreçte küreselleşme ve yeni kamu yönetimi anlayışı uluslararası etkiler yaratırken, bunlara ilaveten 2000'li yılların hemen başında Avrupa Birliği'ne üyelik süreci ve demokratikleşme reformları Türk kamu yönetiminde değişim ve dönüşümü hızlandırıcı etkiler yaratmıştır. Sözü edilen ulusal ve uluslararası etkileşimin bu denli hızlı ve etkili şekilde yayılmasında bilgi iletişim teknolojilerindeki gelişmelerin önemli bir payı olmuştur. Özellikle 1990'lardan itibaren “dijital çağ" olarak adlandırılan dönemde kamu yönetimlerinin değişime ayak uydurması adeta bir zorunluluk haline gelmiştir. 
Birey ve sivil toplumun yükselişe geçmesi kamu hizmetlerinin sunumunda ve devlet-vatandaş ilişkilerinde geçmişin tek yönlü işleyen ilişki tarzını değiştirmiş, ilişkiler, vatandaşların talep ve isteklerinin de rol oynadığı çift yönlü bir etkileşim temelinde ele alınmaya başlanmıştır. $\mathrm{Bu}$ bağlamda yönetişim olarak adlandırılan; kamu- özel sektör ve sivil toplumun birlikte karar aldığı, birbirleriyle etkileşim içinde ve paydaş olduğu bir yönetim iklimi oluşturulmaya çalışılmıştır. Birlikte yönetim modeline ulaşmada son derece demokratik, katılımcı olması bakımından kulağa hoş gelen bu kavramın içinin doldurulabilmesi her şeyden önce bunu vaat eden yönetimlerin sorumluluğunda olmuştur. Bu amaçla, öncelikle bilgi edinme ve hak arama özgürlüğü üzerinden bireyin ve sivil toplumun bilinçlendirilmesi ve güçlendirilmesi gerekmiş, bunun için de sürecin yasal altyapısı hazırlanarak devamında iyi yönetişimi (good governance) sağlayıcı reformlara yer verilmiştir.

Çalışmanın temelinde, bu reform zincirinin en son ve en yeni halkası olan İçişleri Bakanlığının uygulamaya koyduğu "Açık Kapı" uygulaması yer almaktadır. Ancak uygulamanın bir dizi reformla ilişkili olmasından hareketle yönetişim reformlarından ve özellikle bu sürecin önemli aşamalarından olan "Bilgi Edinme Hakkına” ve "E-devlet Platformu” na ayrıca değinilmektedir. Çalışmada “Açık Kapı” uygulamasının önemi ve işleyişi açıklanmakta, uygulamanın güçlü ve zayıf yönleri; Başbakanlık İletişim Merkezi (BİMER) ${ }^{3}$ ve devredildiği Cumhurbaşkanlığı İletişim Merkezi (CİMER) (çalışmada bundan sonra yalnızca CİMER kullanılacak olup yapılan atıflar aynı zamanda BİMER’e de yapılmış sayılacaktır) uygulamaları ile karşılaştırılarak tespit edilmeye çalışılmaktadır.

Çalışmanın; 2000'li yıllarda başlayan bireyin ve sivil toplumun güçlendirilmesini, kamu yönetiminin daha işler hale getirilmesini hedefleyen yönetişim reformlarının son halkasını oluşturan "Açık Kapı” uygulamasının yönetim mecralarında daha görünür kılınmasına katkı yapması, pilot il uygulamaları şeklinde ve yakın zamanda başlayan, henüz hakkında herhangi bir akademik çalışmanın gün yüzüne çıkmadığı uygulamayı tanıtarak farkındalık yaratması ve bundan sonra yapılacak akademik çalışmalara öncülük etmesi beklenmektedir.

\section{Bilgi Toplumu Sürecinde Yönetişim Reformları}

Türkiye, 2000'li yıllarla birlikte iç ve dış dinamiklerin etkisiyle siyasal, sosyal, ekonomik ve yönetsel alanlarda yoğun bir değişim sürecine girmiştir. Türk demokrasisini evrensel ölçütler temelinde kurumsallaştırmak ve pekiştirmek temelinde başlatılan bir dizi anayasal ve yapısal değişiklikler (Dursun, 2007, s.57) kısa sürede tüm alanları etkileme potansiyeli olan kamu yönetiminin değişim ve dönüşümü üzerinden sürdürülmüştür. Söz konusu değişim ve dönüşümün temelinde geniş bir kamusal sorumluluk iddiasına sahip olan ancak bütün bu görevleri tek başına üstlenmeyip sorunları kendi kendine çözebilme yetisine sahip bir topluma yükleyerek, onu, kamu görevlileriyle birlikte hareket etmeye yönelten "aktif devlet" anlayışı yatmaktadır (Özel, 2008, s.151). Bu anlayışın aynı zamanda "aktif vatandaş"1 gerektirdiği iddiasından hareketle; çok aktörlü bir yönetimi öngören yönetişim yaklaşımı öne çıkarılmış, bu

\footnotetext{
${ }^{3}$ Vatandaşların kendileri ve kamuyla ilgili, talep, şikayet, ihbar, görüş ve önerileri ile bilgi edinme haklarına ilişkin idari makamlara yapacakları müracaatlara hızlı ve etkin bir şekilde cevap verilmesi, iş ve işlemlerin merkezden kamu nezdinde takip ve denetimini hedefleyen BİMER, 2006 yılında kurulmuş olup yönetim sistemindeki değişiklikle birlikte CİMER'e devredilmiştir.
} 
bağlamda vatandaşların kamusal karar alma ve hizmet sunma süreçlerine dahil edilebilmesi için bilinçlendirilmeleri ve katılım kapasitelerinin (talep etme, hak arama, şikayet etme, istek ve öneri sunma vb.) artırılmasına yönelik politikalar geliştirilmiştir. Bu çabalar aynı zamanda demokratikleşmenin bir tezahürü olarak bireylerin özgürlük alanının genişletilmesinde kullanılan siyasal mekanizmalar ve yönetim teknolojilerinin de demokratik olup olmadıkları tartışmasında demokrasiden yana bir çıkarım yapılmasına imkan sağlamaktadır (Keyman, 2002, s.205).

Dışarıdan bir baskı olmadan her birinin birbirini etkilediği aktörlerin yarattığı bir yapıyı ya da düzeni belirten "Yönetişim" kavramı (Ergun, 274, s.2008) toplumsal yaşamda; kamu yönetimi, özel sektör, sivil toplum kuruluşları ve bireyler olmak üzere dört boyutta gerçekleşmektedir. Devlet organlarının ve kamu hizmeti veren kuruluşların katılımcılı̆̆ özendirmesi ve buna yönelik araçları oluşturmasıyla başlayan süreç; temel aktör olarak vatandaşların; yurttaş olarak devletten, müşteri olarak şirketlerden ve birey olarak da sivil toplum kuruluşlarından iyi yönetişimi talep etmesi ve bu ilkelerle yaşayarak gelişimin sürdürmesiyle devam etmektedir (Argüden ve Toksöz, 2008, s.8-9).

Kamu yönetimlerinin, yeni kamu yönetimi anlayışının etkisiyle piyasa ve birey odaklı bir dönüşüm sürecine girdiği bu dönemde yönetişim temelli bir anlayışın var olabilmesi için gerekli altyapıyı oluşturması bakımından toplumun yönetime katılma ve yönetim faaliyetlerinden haberdar olma ihtiyacı yönetimlerin açıklık, şeffaflık (saydamlık) ve hesap verebilirlik kapasitelerinin artırılmasını gerektirmiştir. Yönetimde açıklık ve şeffaflık kavramları aynı zamanda yönetim sistemlerinin değişimini ifade eden anahtar terimlerden birisi olup (Eken, 2005 , s.23) yönetimler ve vatandaşlar arasındaki kamusal problemlere daha yararlı ve uygulanabilir çözümler getirecek bir anlayışın oluşmasını sağlamaktadır (Lee ve Johnston, 2016, s.167). Bu aynı zamanda açıklğın ve hesap verme sorumluluğunun yönetimlerin kendi içlerinde yeniden üretilmesini sağlamakta, vatandaşların katılımını teşvik ederek demokrasinin gelişimine de hizmet etmektedir (Gilman ve Whitton, 2016, s.162-163).

2000 'li yıllardan itibaren giderek hızlanan değişim ve dönüşüm sürecinin odak noktasında yer alan yönetişim temelli anlayış ile birlikte özellikle kamu hizmetlerinin çeşitliliği, ulaşılabilirliği, etkinliği ve halkın bu hizmetlerden memnuniyet düzeyi kamu yönetiminin başarısını ölçen temel kriterler olarak öne çıkmıştır. Geçmişin halktan kopuk, buyurgan devlet anlayışının yerini hizmetkâr devlet anlayışına bırakması sürecinde halkın sesine kulak verecek, halka kendisini değerli hissettirecek hak arama ve şikayet mekanizmalarının altyapısını teşkil edecek yasal ve yapısal düzenlemeler olarak Bilgi Edinme Hakkı, CİMER ve Kamu Denetçiliği Kurumu'nun kurulması dikkat çeken somut gelişmelerdir. Belirtilen bu uygulamalar ile etkileşim içerisinde olan ve kamu hizmetlerine elektronik ortamda hızlı ve güvenilir bir biçimde ulaşılmasını sağlayan e-devlet platformu da talep ve takip eden bireyler/toplumun oluşmasında etkili olmuştur. $\mathrm{Bu}$ aşamada, e- devlet platformuna uzanan süreçte kronolojik olarak kendisinden sonra gelen iletişim, hak arama ve şikâyet mekanizmalarının öznesi olan vatandaş taleplerinin yasal alt yapısını oluşturması bakımından Bilgi Edinme Hakkı ve bu hakkın kullanımına ilişkin esasları düzenleyen Bilgi Edinme Kanunu önemli bir aşama olmuştur. 


\section{Bilgi Edinme Hakkı}

Bilgi edinme hakkı ve bilgiye erişim özgürlüğünün yasal olarak ilk kez 1766'da İsveç Parlamentosu tarafından tanınmasının üzerinden iki yüz elli yıl geçmesine rağmen bu hakkın kamu yönetimlerinin dikkatini çekmesi/yayılması ve yasal düzenlemelerle güvence altına alınması son 40-50 yılın konusu olmuştur (Bjorkstrand ve Mustonen, 2006, s.4). Bu durum demokrasinin bu dönemde yükselişe geçmesiyle açıklanabilir. Nitekim bilgiye erişimi kolaylaştıran şeffaflık, demokrasinin en temel konularından birisidir ve demokratik bir toplumda şeffaflık kural, gizlilik ise bir istisnadır. Öte yandan vatandaşlara bilgiye ulaşmaları için yetki verilmesi devlet-vatandaş arasındaki mesafenin en aza indirilmesini sağlamada bir ilke ve ön koşuldur (Luhtanen, 2006, s.56-57).

Şeffaf ve hesap verebilir yönetimlerin oluşmasında kamuoyunun alınan/alınacak kararlar ve uygulamalar hakkında bilgi sahibi olabilmesi önemlidir. Bunun için kamuoyuna açı/net ve sağlıklı bilgi akışının sağlanmasına yönelik yasal alt yapı ve mekanizmaların oluşturulması gerekmektedir. Bu bağlamda tasarısı Adalet Bakanlığınca hazırlanan ve 2004 yılında yasalaşan "4982 sayılı Bilgi Edinme Hakkı Kanunu” önemli bir aşama olup, kanunun uygulama yönetmeliğinin de aynı yıl yayınlanması konuya verilen önemi göstermiştir. Kanunun tasarı aşamasında kamuoyunda çok fazla tartışılmamasında toplumsal aktörlerin tasarı üzerinde hem fikir olması gösterilirken, böyle bir düzenlemenin toplumun açık talebi olmadan Avrupa Birliği üyelik süreciyle ilgili olarak gündeme gelmiş olmasının işlerliğinde ve uygulanmasında bir dezavantaj teşkil edebileceği vurgulanmıştır. Bununla birlikte kanunun kapsamı ve hakkın kullanımına ilişkin düzenlemeler oldukça tatmin edici boyuttadır (Eken, 2005, s.101-102).

Kanunda, herkesin bilgi edinme hakkına sahip olduğu vurgulanarak, Kanunun amacının; demokratik ve şeffaf yönetimin gereği olan eşitlik, tarafsızlık ve açıklık ilkelerine uygun olarak kişilerin bilgi edinme hakkını kullanmalarına ilişkin usul ve esasların belirlenmesi olduğu ifade edilmektedir. Kanunun amacı olarak belirtilen ilkelere uygun olarak gizlilik yerine açıklığın benimsenmesi ve vatandaşlara bilgi edinme hakkı tanınması, iyi çalışan medya araçları ve iyi örgütlenmiş baskı grupları ile birleşince, Türk kamu yönetimi üzerindeki denetim artmış ve çeşitlenmiş, kamu faaliyetlerinin artan görünürlüğü yanlışlıkların örtülmesini güçleştirmiştir (Al, 2005, s.244).

Vatandaşların, Bilgi Edinme Kanununa ilişkin olarak kamu kurum ve kuruluşlarına yaptıkları bilgi edinme başvurularının ilgili idare tarafından karşılanmaması durumunda başvurabilecekleri mercii olarak "Bilgi Edinme Değerlendirme Kurulu” kurulmuştur. Başbakanlığa bağlı olarak faaliyet yürüten Kurulun sekretarya hizmetleri, Cumhurbaşkanlığı Hükümet Sistemine geçişle birlikte Başbakanlığın kaldırılmasıyla 09.07.2018 tarih ve 703 sayılı KHK ile Adalet Bakanlığı'na verilmiştir. Dolayısıyla kamu kurum ve kuruluşlarına yapılmış bilgi edinme hakkının kullanımına ilişkin başvurularda yaşanan aksaklıklar konusundaki talepler Adalet Bakanlığı'na yapılabilmektedir. 


\section{E- Devlet Platformu}

Ülkelerin kamu yönetimlerinin hızla değişen koşullara ayak uydurabilmeleri ve artan toplumsal talepleri/beklentileri karşılayabilmeleri için yeniden gözden geçirilmeleri ve yapılandırılmaları gerekmektedir (Parlak ve Sobacı, 2008, s.349). Türkiye'de özellikle 2000'li yıllardan sonra kamu yönetiminin değişim ve dönüşümüne yönelik gerçekleştirilen reformların teknoloji alanındaki en önemli ayağını e-devlet platformu oluşturmaktadır. Nitekim son otuz yılda bilgi teknolojilerindeki olağanüstü gelişmeler onlarca yıldır arzu edilen kamu yönetiminin ve kamu hizmetlerinin daha etkin, verimli, ulaşılabilir ve sorgulanabilir olmasının sağlanmasında yönetimleri bir yandan sorumluluklarını yerine getirmeye zorlarken diğer yandan bu dönüşümü başarmada onları desteklemiş, ellerini güçlendirmiştir. Bu durum yeni kamu yönetimi anlayışının bir yansıması olarak; bürokrasinin sadece siyasetçiye değil halka karşı da sorumlu olmasını, halkın kamu hizmetlerini ve bürokrasiyi denetlemede etkili bir aktör olarak ortaya çıkmasını kolaylaştırmıştır. Bu bağlamda e- devlet platformu bir yandan kamu hizmetlerinin vatandaşlara elektronik ortamda daha hızlı bir şekilde sunulmasını sağlarken diğer yandan vatandaşları elektronik uygulamaların kullanımına teşvik ederek devlet-vatandaş ilişkisinin/iletişiminin artmasına önemli bir katkı yapmaktadır.

E-devlet Platformunun kamu yönetimleri ve vatandaşlar açısından genel olarak sağladığ faydalar aşağıdaki şekilde sıralanabilir (Ülker, 2002, s.970):

$\checkmark \quad$ Kamusal hizmetlerin yaygın ve erişilebilir hale getirilmesi,

$\checkmark$ Yönetim ve hizmet süreçlerinde vatandaşların taleplerini değerlendirerek katılımcı yurttaşlı̆̆ın önünün açılması,

$\checkmark$ Kamu kuruluşlarının çalışmalarında ve hizmet sunumunda rasyonelliğin ve verimliliğin sağlanması,

$\checkmark$ Kamu kurumları ve kullanıcıları arasında iletişim ve koordinasyonun sağlanması,

$\checkmark$ Kamu hizmetlerinin sunumunda maliyet, zaman ve işgücü alanlarında tasarruf sağlanması,

$\checkmark \quad$ Şeffaflık ve güven ortamının sağlanarak devletin vatandaş nezdindeki meşruluğunun pekiştirilmesi,

$\checkmark$ Zaman ve mekân kısıtlamalarının ortadan kaldırılarak devletin 7/24 ulaşılabilir olmasının sağlanması

E-devlet uygulamaları vatandaşlar ve iş dünyasına elektronik bilgi ve hizmet sunmak amacıyla 1990’lı ylllarda gündeme gelirken (Yılmaz ve Bozkurt, 2014, s.295), 1998'de E-devlete geçiş vizyonu oluşturulması amacıyla kurulan "KamuNet Teknik Kurulu" nun çalışmalarından sonra 2003'de “e-dönüşüm Türkiye Projesi”nin başlatılmasıyla daha görünür hale gelmeye başlamıştır. Bilgi teknolojileri temelli E-devlet uygulamaları, vatandaşlar başta olmak üzere kamu kurumları ve iş dünyasını içeren yönetişim temelli işbirliklerinin oluşması ve çeşitli kesimlere sunulan kamu hizmetlerinin verimliliğini arttırma imkânı sağlamaktadır (Carter ve Belanger, 2005, s.5).

\footnotetext{
${ }^{4} 1998$ yılında Başbakanlık genelgesiyle oluşturulan KamuNet Teknik Kurulu, gerek e-Avrupa+ gerekse e-Türkiye çalışmaları doğrultusunda e-Devlete geçiş vizyonunu oluşturarak; bilgi toplumuna geçiş sürecinde bilgi ve iletişim teknolojilerinin getirdiği olanaklardan yararlanarak, devletin etkin, şeffaf, güvenli, hızlı ve kesintisiz hizmet sunacak; e-Kurumların oluşturulmasını sağlamak, devlet ve vatandaş arasındaki ilişkileri elektronik ortama taşımak için Devlet e-Kapısını (portalını) oluşturmak amacıyla kurulmuştur (DPT, 2002).
} 
18 Aralık 2008 tarihinden bu yana hizmet vermekte olan E-devlet platformunda 01.06.2019 tarihi itibariyle 597 kuruma ait 4778 hizmete online olarak erişim sağlanmaktadır. Bu hizmetlerin 2218'ine aynı zamanda mobil uygulama olarak ulaşılabilmektedir. Platform, 42.609.000'e ulaşan kayıtlı kullanıcı sayısıyla uygulamayı kullanabilecek yaştaki Türkiye nüfusunun 2/3'ünü kapsamına almıştır (TÜİK, 2018). ${ }^{5}$

\section{Açık Kapı Uygulaması}

2000'li yıllardan itibaren kamu yönetimi ve kamu hizmetlerinin değişim, dönüşüm ve gelişiminde görülen ilerlemelerde bilgi iletişim teknolojilerinin önemli payı bulunmaktadır. $\mathrm{Bu}$ süreçte bireylerin yönetime talep, istek, öneri ve şikayetlerini iletmede çok önemli işlevleri yerine getiren CİMER gibi halkla ilişkiler uygulamalarının son halkasını İçişleri Bakanlığı'nın yürüttüğü “Açık Kapı” uygulaması oluşturmaktadır.

Açık Kapı uygulaması, İçişleri Bakanlığının; valilik ve kaymakamlıklara yapılan başvurulara ilişkin iş ve işlemlerin hızlı ve etkin bir şekilde sonuçlandırılmasını temin etmek, sunulan hizmetlerde vatandaş memnuniyetini arttırmak, talep ve beklentilerin analiz ve raporlamalarının yapılarak, oluşturulacak yeni yönetim politikalarına ve hizmet sunum tekniklerine esas olmak üzere anlamlı veriler haline getirilmesini sağlamak amacıyla oluşturulan bir halkla ilişkiler uygulamasıdır (Açık Kapı Yönergesi, 2017). Uygulamanın merkezi düzeyde planlanması ve koordinasyonu, en üst düzeyde İçişleri Bakanlığı Stratejik Yönetim Koordinasyon Dairesi Başkanlığı tarafından gerçekleştirilmektedir.

Açık Kapı uygulamasının başvuru kanalları ve web sayfası görünümü bakımından CİMER'den farkı, Açık Kapı uygulamasının bir bakanlık uygulaması (İçişleri Bakanlığı) olmasıdır. CİMER uygulaması yerelden merkezi yönetime uzanan çok daha kapsayıcı bir proje olarak işlev görürken Açık Kapı uygulamasının, en yetkili kullanıcısı mülki idare amiri olan, il ölçeğinde planlanan bir proje olduğu görülmektedir.

Açık Kapı uygulamasının il ölçeğinde planlanan ve yürütülen bir proje olması ilk bakışta uygulamaya lokal bir proje görüntüsü vererek önemi azaltan bir görüntü vermesinin aksine; sorunların, kaynağına en yakın yerde çözümünü sağlaması bakımından daha hızlı ve etkin olunmasına olanak sağlamaktadır. Uygulama bu niteliğiyle subsidiarite ilkesinin merkezi yönetimin taşra teşkilatındaki bir uygulama örneği olarak nitelendirilebilir.

\section{Açık Kapı Uygulamasının İşleyişi}

Aralık 2017'de 15 pilot ilde başlatılan Uygulama, Şubat 2018'de 47 ile yayılmış, günümüzde ise 81 ili ve Ankara, İstanbul ve İzmir'in merkezinde yer alan 48 ilçeyi kapsar hale gelmiştir.

Açık Kapı Projesi içerisinde; "Vatandaş, Açık Kapı Sorumlusu (AKS), Yetkili ve Mülki İdare Amiri (MİA)” olmak üzere dört farklı kullanıcı tipi bulunmaktadır. Vatandaş,

\footnotetext{
${ }^{5}$ TÜİK'in 2018 yılı adrese dayalı nüfus kayıt istatistiklerine göre Türkiye'nin 18 yaşın üzerindeki nüfusu yaklaşık 61 milyondur. 18 ve üzeri yaş, E-devlet Platformunun içerdiği hizmetlerin özellikleri ve resmi nitelikleri bakımından yazarlar tarafından Platformu kullanabileceklerin yaş eşiği olarak düşünülmüştür.
} 
$\checkmark$ CIMER uygulaması ulusal ölçekte işlerken, Açık Kapı uygulamasının il ölçeğinde işlemesi bir diğer farklı yönü oluşturmaktadır. Bu bağlamda Açık Kapı uygulaması yerelde, il/ilçe ölçeğinde daha dinamik bir kamu hizmeti anlayışını tesis etmeye yönelik olarak planlanmıştır.

$\checkmark \quad$ Uygulamayla; ilin yoğunluklu başvuru türlerinin, sorun alanlarının, hizmetin aksayan yönlerinin, iyi uygulamaların, coğrafi, demografik ve sosyo-ekonomik açlardan tespit edilmesi; "idari merkeziyetçiliğin" hakim olduğu kamu yönetimi örgütlenmesinin vatandaşa en yakın olduğu yereldeki/il ölçeğindeki performansını değerlendirebilmek açısından önemli veriler sağlamaktadır.

Açık Kapı uygulaması aşağıda (Şekil 1) de yer alan organizasyon şemasında görüleceği üzere valilikler ve kaymakamlık düzeyinde işlemektedir. Uygulama sürecinde il ve ilçe bazında örgütlenen kamu kurum ve kuruluşlarının iletişim ve irtibatının sağlanması amacıyla söz konusu kurumlarda irtibat görevlileri belirlenmektedir. Bu bakımdan il içerisinde tüm kamu kurum ve kuruluşlarının Açık Kapı uygulaması üzerinden bir ağ şeklinde iletişimi sağlanmaktadır. Uygulamanın en yetkili kullanıcıları mülki idare amirleri yani illerde valiler, ilçelerde kaymakamlardır.

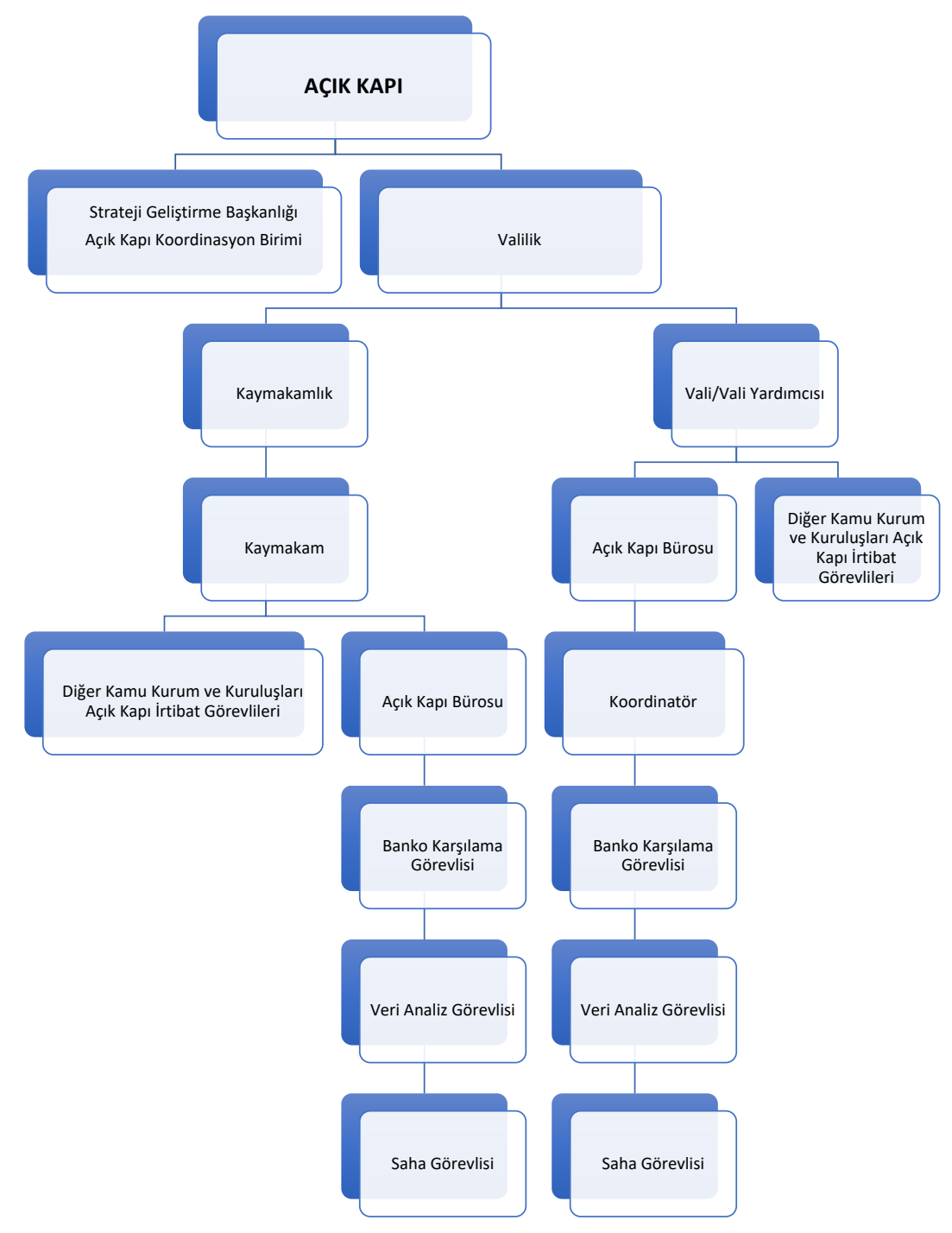

Kaynak: Açık Kapı Yönergesi, 2017

Şekil 1. Açık Kapı Uygulaması Organizasyon Şeması 
Açık Kapı uygulamasının işleyişi, başvuruların sayısı ve sonuçları ile ilgili olarak; uygulamaya dair istatistiksel bilgilerin paylaşıldığı bir platformun olmaması nedeniyle yazarlar tarafından 11.01.2019 tarihinde CİMER kanalıyla İçişleri Bakanlığına Bilgi Edinme Başvurusu yapılmış, uygulamaya ilişkin veriler bakanlık cevabında yer alan bilgiler ışığında aşağıdaki şekilde (Şekil 2) açıklanmıştır.

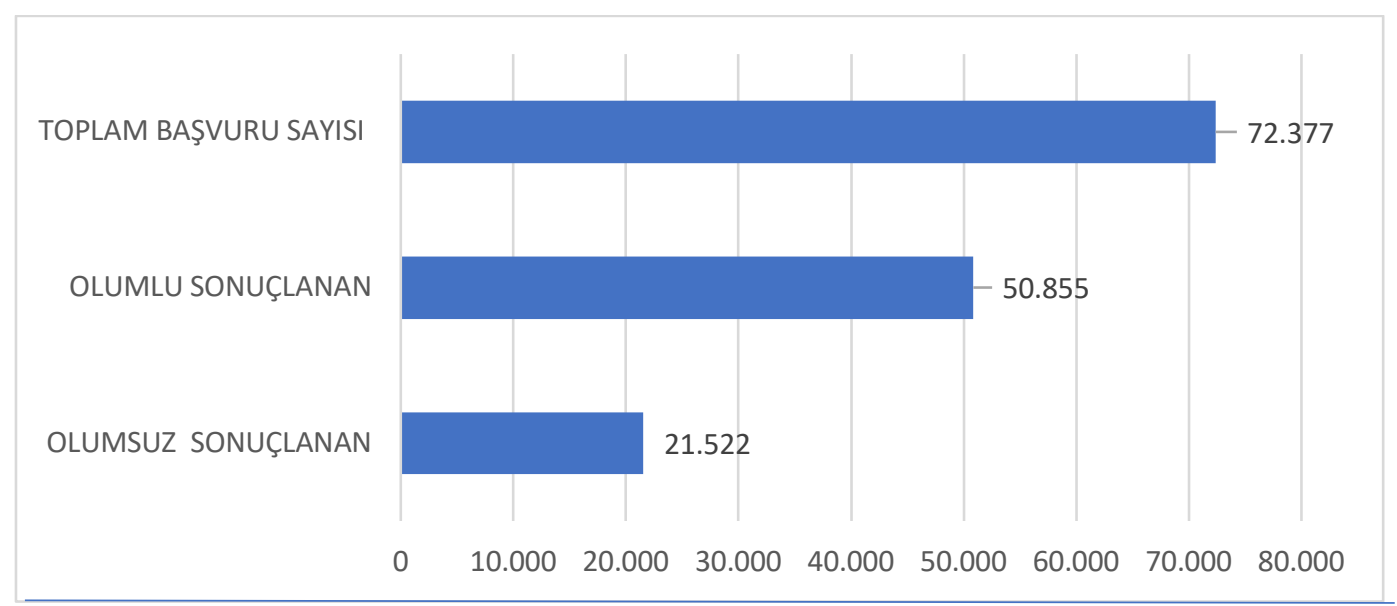

Şekil 2. (15.12.2017- 21.01.2019) Tarihleri Arasında Türkiye Genelinde Açık Kapı Bürolarına Yapılan Başvuru Sayısı

11.01.2019 tarihinde İçişleri Bakanlığı’na yapılan “Bilgi Edinme Başvuru”suna Bakanlık Strateji Geliştirme Başkanlığınca verilen yanıtta; Açık Kapı Bürolarının 81 il valiliğinde ve Ankara, İstanbul ve İzmir il merkezlerinde bulunan 48 ilçede kurularak faaliyete başladığı belirtilmiştir. Açık Kapı Uygulamasının başlangıcından 21.01.2019 tarihine kadar geçen sürede Türkiye genelinde ilgili bürolara 72.377 başvuru yapılmış, bu başvuruların 50.855 'i $(\% 70,3)$ "olumlu" olarak cevaplandırılmıştır. Bilgi Edinme talebine verilen cevapta sayı ve yüzdeler belirtilmemekle birlikte belirlenen 17 hizmet kategorisinde başvuru yoğunluğuna göre en yoğun başvuruların sırasıyla; Sosyal Hizmetler, Çalışma ve Sosyal Güvenlik, Yerel Yönetimler, Eğitim, Valilik Hizmetleri kategorilerinde gerçekleştirildiği belirtilmiştir

Açık Kapı uygulamasının ulusal ölçekteki genel değerlendirmesinin yanında yereldeki görünümüne örnek teşkil etmesi bakımından projenin başladığı Aralık 2017 tarihinde belirlenen 15 pilot ilden birisi olan Balıkesir ilindeki sayısal verilere aşağıda yer alan iki şekilde (Şekil 3 ve Şekil 4) değinilmiştir. Şekil 3 ve Şekil 4, Balıkesir Valiliği Açık Kapı bürosundan elde edilen verilere dayanılarak yazarlar tarafından oluşturulmuştur. 


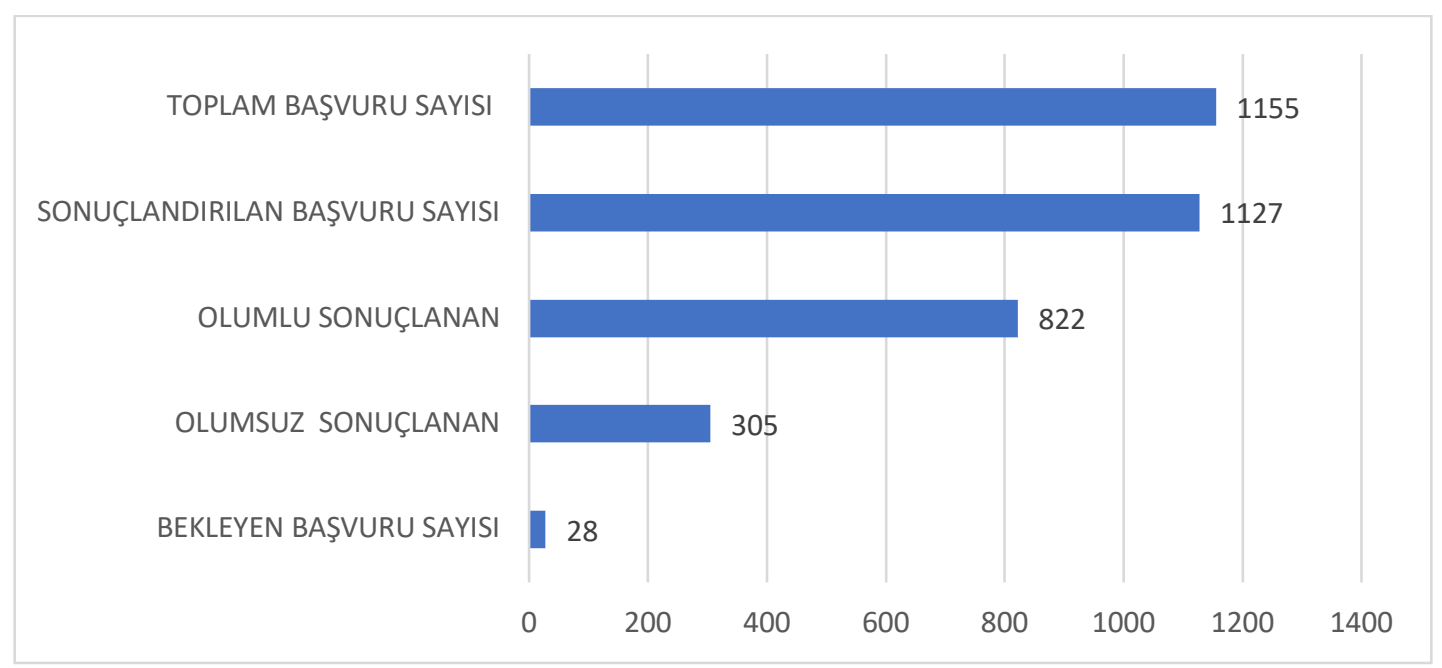

Şekil 3. (22.12.2017- 10.01.2019) Tarihleri Arasında Balıkesir Valiliği Açık Kapı Bürosuna Yapılan Başvuru Sayısı

22.12.2017- 10.01.2019 tarihlerini kapsayan yaklaşık bir yıllık periyotta Balıkesir Valiliği Açık Kapı bürosuna 1155 başvuru yapılmış, sonuçlandırılan 1127 başvurunun 822'si (\% 72,9) olumlu, 305'i (\% 27,1) olumsuz sonuçlanmıştır. Sistemde henüz cevaplandırılmamış 28 başvuru bulunmakta olup, söz konusu başvurular için 7 günlük cevaplandırma süresi bulunmaktadır. Balıkesir Valiliği Açık Kapı bürosuna yapılan ziyarette elde edilen yukarıdaki verilerin yanı sıra tespit edilen diğer bir husus ise; büronun gerçekleştirdiği danışma ve yönlendirme faaliyetlerinin, büroya yapılan ve yukarıda belirtilen başvuru sayılarından çok daha fazla olmasıdır. Nitekim 2018 Aralık ayında Açık Kapı uygulaması kapsamında toplam 86 başvuru yapılırken, büroda kayıt altında alınmış toplam yönlendirmenin 1040, toplam danışma sayısının 1036 olduğu tespit edilmiştir. Bu durum Açık Kapı bürolarının görev tanımları arasında yer alan, "valilik/kaymakamlıklara gelen tüm vatandaşların her türlü bilgi ve yardım talepleriyle" ilgilenildiğini ve arka planda, istatistiklere yansımayan çok daha büyük bir halkla ilișkiler faaliyetinin yürütülmekte olduğunu göstermektedir. 


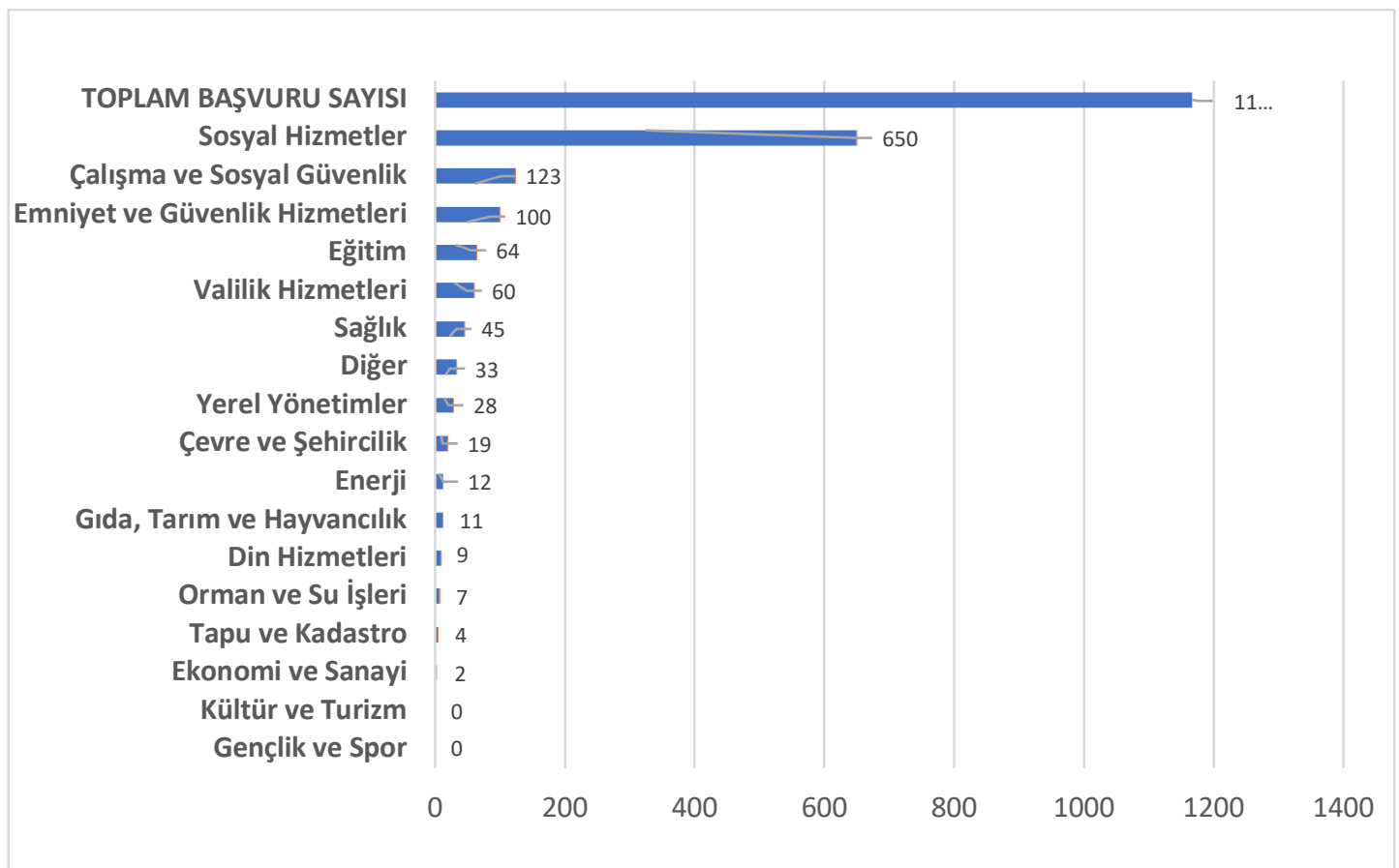

Şekil 4. (22.12.2017- 10.01.2019) Tarihleri Arasında Balıkesir Valiliği Açık Kapı Bürosuna Yapılan Başvuruların Konularına Göre Dağılımı

22.12.2017- 10.01.2019 tarihlerini kapsayan dönemde yapılan başvuruların konularına göre dağılımı Şekil 4'te yer almaktadır. Buna göre başvuru yoğunluğunda ilk beş sırada sırasıyla; Sosyal Hizmetler 650 başvuru (\% 56,3), Çalışma ve Sosyal Güvenlik 123 başvuru (\% 10,6), Emniyet ve Güvenlik Hizmetleri 100 başvuru (\% 8,7), Eğitim 64 başvuru (\% 5,5) ve 60 başvuruyla (\% 5,2) Valilik Hizmetleri'nin yer aldığı görülmektedir. 17 farklı konunun yer aldığ şekilde sözü edilen ilk beş konu tüm başvuruların \% 86,3’ünü teşkil etmektedir.

Balıkesir ili açısından dikkat çeken bir husus; başvuru yoğunluğuna göre yapılan ilk beş hizmet kategorisi sıralamasında, Balıkesir ili ve Türkiye genelindeki sıralamanın 4 hizmet kategorisinde (1. Sosyal Hizmetler, 2. Çalışma ve Sosyal Güvenlik, 4. Eğitim ve 5. Valilik Hizmetleri) aynı olmasıdır, Diğer yandan sıralamada Türkiye genelinde 3. sırada yer alan Yerel Yönetimler kategorisinin Balıkesir'de 8. sıraya gerilediği ve Balıkesir'de 3. sıraya Emniyet ve Güvenlik Hizmetlerinin yerleştiği görülmektedir. Bu durum Balıkesir'de söz konusu dönemde Türkiye sıralamasıyla karşılaştırıldığında Yerel Yönetim Hizmetlerinde görece sıkıntı olmadığı, Emniyet ve Güvenlik Hizmetlerinin ise vatandaşlar tarafından daha problemli ve/veya öncelikli görüldüğü şeklinde yorumlanabilir.

\section{Açık Kapı Uygulamasının Güçlü ve Zayıf Yönleri}

Açık Kapı uygulaması bilgi teknolojileri ve yüz yüze iletişimin birlikte kullanıldığı bir halkla ilişkiler uygulamasıdır. Valilik ve kaymakamlıkların girişinde oluşturulan büro ve danışma bankolarıyla vatandaşın kuruma ilk girişinde dikkatinin çekilmesine çalışılan uygulamanın; henüz bir yılı doldurmuş yeni bir uygulama olmasına rağmen, bilgi edinme ve kamu hizmetlerine ilişkin talep, istek, şikayet ve öneri sunan diğer bir uygulama olan CİMER ile karşılaştırıldığında bir takım güçlü ve/veya geliştirilmesi gereken yönlerinin bulunduğu görülmektedir. 


\section{Güçlü Yönler;}

$\checkmark \quad$ Uygulamaya Olan İhtiyaç: Türkiye'de Cumhurbaşkanlı̆̆ı Hükümet Sistemine geçildiği 2018'den önce BİMER ve CİMER olarak iki kanaldan alınan vatandaş talep istek, öneri, şikayet vb. başvurularının bu tarihten sonra BİMER'in CİMER'e devredilmesiyle tek kanala düşmesi CİMER sisteminde büyük bir yoğunluğun oluşmasına neden olmuştur. Dolayısıyla bu büyük iş yükünün azaltılmasına olan ihtiyaç, sorunların merkeze/bakanlıklara taşınmasını önleyecek yerel bir mekanizma olarak Açık Kapı uygulamasının önemini arttırmaktadır.

$\checkmark \quad$ Kamu Yönetiminin Daha İyi İşlemesine Yapacağı Katkı: Türkiye’de merkezi idarenin taşra teşkilatı il sistemine göre örgütlenmiştir. Cumhurbaşkanlığı Hükümet Sistemiyle merkezi yönetimde yapılan değişikliklerle kamu yönetimin daha hızlı karar alan dinamik bir yapıya kavuşturulması amaçlanırken, Açı Kapı uygulamasıyla bu yapının devamı ve vatandaşlara en yakın birimler olan taşra örgütünün merkezdeki değişime paralel olarak vatandaşla iç içe, daha dinamik, sorunların merkeze aktarılmadan il ölçeğinde çözüldüğü, vatandaş denetiminin sağlandığı iyi işleyen bir kamu yönetiminin oluşturulmasına katkı yapacaktır.

$\checkmark \quad$ Vatandaşlarla Yüz Yüze İletişim İmkanı: İletişimde birden fazla duyu organının birlikte kullanılması en etkili yöntem olarak kabul edilmektedir. Bu bakımdan Açık Kapı uygulamasının en önemli avantajı vatandaşların güler yüzle karşılandığı, onlarla ilgilenecek insanların görevlendirildiği, yüz yüze iletişimi esas alan yapısıdır. Nitekim kamu yönetiminin vatandaşa olan bakışında 2000'li yıllarda önemli değişimler gerçekleşse de kamu kurum ve kuruluşlarına işi düştüğünde tedirgin olan vatandaş sayısı halen azımsanmayacak kadar çoktur. Bu bakımdan Uygulama vatandaş nezdinde "devletin/kamu yönetiminin gülen yüzü" olmaya adaydır.

$\checkmark \quad$ İl Ölçeğinde Kamu Hizmetlerine İlişkin Durum Tespiti Yapma: İlin yoğunluklu başvuru türlerinin, sorunların, aksayan yönlerin, iyi uygulamaların coğrafi, demografik ve sosyoekonomik açlardan tespit edilmesi ve analizi bu hizmetlere ilişkin kamu politikalarının illerin ihtiyacına göre daha iyi planlanmasında önemli olacaktır. Nitekim her ilde kamu hizmetlerine olan talepler birbirinden farklı olabilmektedir.

\section{Zayıf Yönler;}

$\checkmark \quad$ Uygulamanın Düşük Yaygınlaşma Hızı: İçişleri Bakanının ifadesiyle; Açık Kapı uygulaması, başta Hazine ve Maliye Bakanlığı olmak üzere başka hiçbir bakanlığa ek bir maliyet yüklemeden tamamen İçişleri Bakanlığının kendi kaynaklarını kullanarak oluşturduğu bir uygulamadır. Uygulamada görev alan personel, kullanılan araçgereç, yazılım, sistemin geliştirilmesi vb. tüm ihtiyaçların yalnızca Bakanlığın kendi kaynaklarından karşılanması uygulamaya, Bakanlık özelinde yavaş yavaş gelişen lokal bir proje görüntüsü vermektedir.

$\checkmark \quad$ CIMER Uygulamasına Göre Düşük Görünürlüik/Bilinirlik: Açık Kapı uygulaması benzer kategoride değerlendirilebilecek CIMER uygulamasına göre daha "düşük görünürlüğe" ve "daha az bilinirliğe" sahiptir. Bu durumun iki temel nedeni; bütçe ve kullanılan kaynaklar anlamında Açık Kapı uygulamasının, CİMER uygulamasına 
göre kaynak kullanımının daha düşük boyutlu oluşu ve ulusal çapta uygulanan CIMMER uygulamasının aksine Açık Kapı uygulamasının il ölçeğinde/yerelde uygulanmasıdır. Bilbordlarda ve valiliklerin internet sayfalarında yapılan görsel duyurular ile vatandaşların uygulamadan haberdar olması sağlanmaya çalışılmaktadır. Daha sonraki dönemlerde uygulamanın kiosklar ve oluşturulacak "Açık Kapı Çağrı Merkezleri” ile yaygınlaştırılması hedeflenmektedir. Görünürlüğü azaltan diğer bir husus ise Açık Kapı uygulamasına ait kurumsal internet sayfasının bulunmamasıdır. Uygulama süreci hakkında genel bilgi ve istatistiksel bilgilerin kamuoyunun ve araştırmacıların bilgisine sunulacağı kurumsal bir web sayfasının olmayışı konuya ilişkin kamuoyundan gelecek bilgi ve belge taleplerinin ancak CIMER yoluyla karşılanabilmesine neden olmaktadır.

\section{Sonuç ve Değerlendirme}

Dünya 20. yüzyllda kamu yönetimlerinin yükselişine tanık olurken yüzylın sonlarında geleneksel kamu yönetiminin değişim sürecine girdiği, bununla birlikte sahneye birey ve sivil toplumun çıktığı yeni bir dönem yaşanmaya başlanmıştır. Bu dönemin genel karakteristiği neoliberal geleneğin vatandaş/birey hakları üzerinden yönetimleri şekillendirmesi olmuştur. Küreselleşme olgusunun da desteğiyle kamu yönetimleri, geçmişin korumacı, gizlilik ve kapalılık esaslı, vatandaşından kopuk yönetim anlayışını terk etme baskısıyla karşılaşmışıır. Bilgi iletişim teknolojilerindeki muazzam gelişmelerin de destek verdiği bu süreçte devlet ile birey arasındaki iletişimde yeni alanlar yaratılarak önemli ilerlemeler sağlanmıştır.

Küresel çapta yaşanan bu gelişmelerden Türkiye de etkilenmiş, bu etkileşim 2000'li yıllardan sonra kamu yönetiminde değişim ve dönüşümü amaçlayan hükümetlerin işbaşına gelmesiyle ivme kazanmıştır. Bireyin ve sivil toplumun haklar bağlamında geliştirilmesi demokratikleşme sürecinin en önemli bileşenlerinden birisi olarak düşünülmüştür. $\mathrm{Bu}$ amaçla öncelikle bireylerin bilgi edinme haklarının tanınması ve etkin kullanımını sağlayacak yasal altyapının oluşturulması sağlanmış, hayata geçirilen halkla ilişkiler mekanizmalarıyla devlet-birey arasındaki mesafenin azaltılmasına çalışılmıştır.

2006 yllında BİMER adıyla oluşturulan ve 2018'de CİMER olarak devam eden "şikayet, istek ve öneri mekanizması” vatandaşlardan yoğun ilgi görmüsstür/görmektedir. Diğer taraftan E-devlet portalı üzerinden sayıları binlerle (01.06.2019 tarihi itibariyle 597 kuruma ait 4778 hizmet) ifade edilebilecek kamu hizmetinin vatandaşların kullanımına sunulması kamu yönetimindeki değişimi hızlandırmıştır. 2017 ylı sonlarında, Türkiye'de yönetim sistemindeki değiş̧ikliğe paralel olarak kamu kurum ve kuruluşlarından hizmet alan vatandaşların, hizmetlere ilişkin sorunlarının merkezi yönetime aktarılmadan kaynağında/yerelde çözülmesine yönelik bir uygulama olarak İçişleri Bakanlığı tarafından yürütülen "Açık Kapı" uygulaması başlatılmıştır. Gelinen süreçte "Açık Kapı" uygulamasının bir takım güçlü ve zayıf yönlerinin bulunduğu değerlendirilmiştir. 
Uygulamanın güçlü yönleri aşağıdaki gibi belirtilebilir:

$\checkmark$ Vatandaş ile bire bir ve yüz yüze iletişimi önceleyen bir formatta planlanan, etkili bir halkla ilişkiler politikası olması,

$\checkmark$ İl ve ilçe boyutunda kamu hizmetlerinden memnuniyetsizliklerin gerek CİMER gerekse diğer kanallar (idare mahkemesine, kamu denetçiliğine başvuru vb.) üzerinden merkeze taşınmasıyla oluşacak iş yükünü minimuma indirecek bir yapıda olması,

$\checkmark$ Kamu yönetiminin taşra teşkilatının yerel dinamiklerin etkisiyle daha etkin ve verimli şekilde çalışmasına, sorunların doğduğu yerde çözülmesine katkı yapacak ve vatandaşların öneri, istek, talep, şikayet ve bilgi alma haklarını kullanarak yönetime katılım imkanlarını arttıracak bir içeriğe sahip olması

Uygulamanın zayıf/geliştirilmesi gereken yönleri ise,

$\checkmark$ Uygulamanın kamuoyundaki görünürlüğü/bilinirliğinin düşük olması.

$\checkmark$ Uygulamaya ait genel bilgilerin, başvurulara ait istatistiksel verilerin ve uygulamanın geleceğine/sürdürülebilirliğine ilişkin politikaların duyurulacağı, araştırmacıların ve kamuoyunun bilgisine sunulacağı mecraların (internet sitesi, basın bilgilendirmesi, medyada yayınlanacak kamu spotu vb.) oluşturulmamış olması

olarak belirtilebilir. 17 pilot il ile başlayarak zamanla yaygınlaştırılan ve yaygınlaştırma süreci ulusal çapta duyurumlara başvurulmadan sessiz sedasız gerçekleştirilen uygulamanın önümüzdeki süreçte daha görünür kılınması amacıyla daha etkili bir duyurum ve tanıtım politikasılla desteklenmesi gerekmektedir.

Betimleyici (descriptive) ve açılayıcı (explanatory) bir yöntemle gerçekleştirilmesi ilk bakışta çalışmanın zayıf yönü olarak değerlendirilebilinirse de, gerçekte “Açık Kapı” uygulamasının henüz yeni, ampirik (görgül) bir araştırmayı olanaklı kılacak olgunluğa ulaşmamış olması ve bu tür bir araştırmayı destekleyecek yeterli verinin henüz oluşmamasının araştırma yönteminde bir kısıt olarak ortaya çıktığı görülmektedir. Ancak çalışma, “Açık Kapı” uygulamasını konu alan/değerlendiren ilk bilimsel araştırmalardan olma iddiasıyla önem kazanmaktadır. Öte yandan "Açık Kapı" uygulamasının yukarıda bahsedilen eksikliklerinin (internet sitesi, istatistiksel veri ve bilgi paylaşımı sorunu) giderilmesi halinde araştırmacıların daha fazla ilgisini çekeceği ve yeni/farklı çalışmalara kaynaklık edeceği muhakkaktır.

\section{Kaynakça}

Açık Kapı Yönergesi (2017). Açık Kapı Kuruluş, Çalışma Usul ve Esasları Yönergesi. http://www.eskisehir.gov.tr/kurumlar/eskisehir.gov.tr/ilan/yonerge.pdf

Al, H. (2005). Türk Kamu Yönetiminde Yolsuzlukla Mücadele: Geleneksel Bürokratik Yapı ve Yeni Etik Değerler, http://www.etiksempozyumu.sakarya.edu.tr/ etik/3.1/2Hamza\%20 AL.pdf (02 Mart 2019).

Argüden, Y., Toksöz, F. (2008). İyi Yönetişim El Kitabı, İstanbul: TESEV. 
Björkstrand, G., Mustonen, J. (2006). Introduction: Anders Chydenius' Legacy Today, The World's First Freedom of Information Act (içinde), Juha Mustonen (Ed.), (s.4-6), İsveç: Anders Chydenius Foundation.

Carter, L., Belanger, F. (2005). The Utilization of E-government Services: Citizen Trust, Innovation and Acceptance Factors, Info System Journal, 15(1), 5-25.

DPT (2002). e-Devlet'e Geçiş Sürecinde KamuNet Çalışmaları. http://www.bilgitoplumu.gov.tr/wp-content/uploads/2014/04/e-

Dursun, D. (2007). Türkiye’nin Dönüşüm Süreci, Dinamikleri ve Genel Özellikleri, D. Dursun, B. Duran ve H. Al (Ed.), Dönüşüm Sürecindeki Türkiye içinde, (s. 17- 64), İstanbul: Alfa.

Eken, M. (2005). Yönetimde Şeffaflık, Adapazarı: Sakarya.

Ergun, Turgay (2008). Yönetişim, Kamu Yönetimi Sözlüğ̈̈, Ömer Bozkurt, Turgay Ergun ve Seriye Sezen (Eds.), Ankara: TODAİE Yayın No: 342.

Gilman, S.C., Whitton, H. (2016). When Transparency Becomes the Enemy of Accountability, Corruption and American Cities Essays and Case Studies in Ethical Accountability (içinde), Joaquin Jay Gonzalez III ve Roger L. Kemp (Eds.), (s. 165-167), North Carolina: McFarland.

Keyman, E. F. (2002). Globalleşme Söylemleri, Özgürlük Sorunsalı ve Türkiye, Liberalizm, Devlet, Hegemonya içinde, E.Fuat Keyman (der.), (s. 199-213), İstanbul: Everest.

Lee, J., Johnston, E.W. (2016). How to Embed Transparency into Collaborative Governance, Corruption and American Cities Essays and Case Studies in Ethical Accountability (içinde), Joaquin Jay Gonzalez III ve Roger L. Kemp (Eds.), (s. 165-167), North Carolina: McFarland.

Luhtanen, L. (2006). Transparency at the Core of Democracy, The World's First Freedom of Information Act (içinde), Juha Mustonen (Ed.), (ss.56-58), İsveç: Anders Chydenius Foundation.

Parlak, B., Sobac1, Z. (2008). Kuram ve Uygulamada Kamu Yönetimi Ulusal ve Global Perspektifler, Bursa: Alfa Aktüel

Özel, Mehmet (2008). Devletin İşlevsel Dönüşümü ve Genel Kamu Yönetimi Üzerine Etkileri, Devletin Dönüşümü ve Yeni Dönem Kamu Yönetimi içinde, (s. 129-181), Mehmet Özel\& Veysel Eren (Eds.), Konya: Çizgi.

TÜİK (2018). Adrese Dayalı Nüfus Kayıt İstatistikleri 2018 Yılı Türkiye 18 Yaş Üstü Nüfus Raporu, https://biruni.tuik.gov.tr/medas/?kn=95\&locale=tr

Ülker, H. (2002). "Bilgi Toplumu ve Devlet”, I. Ulusal Bilgi, Ekonomi ve Yönetim Kongresi, Kocaeli Üniversitesi, İktisadi ve İdari Bilimler Fakültesi Yayını, İzmit.

Yılmaz, A., Bozkurt, Y. (2014). Türkiye'de E-Devlet Pratiğinin Atipik Bir Örneği: Tek Adımda Hizmet Birimleri, Cumhuriyet Üniversitesi İktisadi ve İdari Bilimler Dergisi, 15(1), 293311. 